\title{
The Best of Village Head Performance: Simple Additive Weighting Method
}

\author{
Ambika P., B. Ayshwarya, Phong Thanh Nguyen, Wahidah Hashim, Fatma Rinjani, Muhamad \\ Muslihudin, K. Shankar, Oksana P. Denisova, Andino Maseleno
}

\begin{abstract}
The village head is the leader of the village level government. Achieving the development of a village demands the role of a qualified village head. His role, duties, and responsibilities are crucial to the progress of the village. Simple Additive Weighting (SAW) method is one of the methods in decision support system where alternative and criteria have been determined. Criteria that have been determined include: gender, how long served, how the facilities and infrastructure, achievement of the program, and the welfare of the community. Based on the results of research that has been done in Pagelaran Subdistrict of ten alternatives in the trial then there is a ranking order ranking as follows $A 3$ with the largest value $1 ; A 1=0,9 ; A 5=0,85$; $A 10=0,83 ; A 2=0,83 ; \quad A 6=0,78 ; A 7=0,68 ;$ $A 4=0,58 ; A 9=0,51$, and $A 8$ has a value of 0.31 which is the lowest value of the alternatives already in trial.
\end{abstract}

Index Terms: Village head, simple additive weighting, village head performance.

\section{INTRODUCTION}

In this era of globalization, the development of science, information and communication technology has been growing rapidly and increasing the quality of human life. A developed country is based on how far this nation has mastered these two regions. The head of village is the leader of the village level government. The head of village is also the leader of the village administration. The achievement of a village's development requires the role of a qualified leader to keep pace with the demands of progressive change. Therefore, it is better for each Head of Village to improve the quality of his leadership style to bring his village towards the

Revised Manuscript Received on July 22, 2019.

Ambika P., Department of Computer Science, Kristu Jayanti College, Bangalore-560043, India.

B. Ayshwarya, Department of Computer Science, Kristu Jayanti College, Bangalore-560043, India.

Phong Thanh Nguyen, Department of Project Management, Ho Chi Minh City Open University (HCMCOU), Vietnam. Universiti Tenaga Nasional, Malaysia.

Fatma Rinjani, Department of Information Systems, STMIK Pringsewu, Lampung, Indonesia.

Muhamad Muslihudin, Department of Information Systems, STMIK Pringsewu, Lampung, Indonesia.

K. Shankar, School of Computing, Kalasalingam Academy of Research and Education, Krishnankoil, India.

Oksana P. Denisova, Togliatti State University, Russia

Andino Maseleno, Institute of Informatics and Computing Energy, Universiti Tenaga Nasional, Malaysia. E-mail: andimaseleno@ gmail.com
Wahidah Hashim, Institute of Informatics and Computing Energy,

more advanced. Pagelaran Sub-district is one of 9 sub-districts in Pringsewu District which has 22 villages.

Table 1: Number of villages and urban villages per sub-district in Pringsewu District 2016

\begin{tabular}{|c|l|c|c|c|}
\hline No & Sub District & Urban Village & Village & Total \\
\hline 1. & Pardasuka & - & 13 & 13 \\
\hline 2. & Ambarawa & - & 8 & 8 \\
\hline 3. & Pagelaran & - & 22 & 22 \\
\hline 4. & $\begin{array}{l}\text { Pagelaran } \\
\text { Utara }\end{array}$ & & 10 & 10 \\
\hline 5. & Pringsewu & 5 & 10 & 15 \\
\hline 6. & Gadingrejo & - & 23 & 23 \\
\hline 7. & Sukoharjo & - & 16 & 16 \\
\hline 8. & Banyumas & - & 11 & 11 \\
\hline 9. & Adiluwih & - & 13 & 13 \\
\hline & Total & 5 & 126 & 131 \\
\hline
\end{tabular}

Source: Pringsewu district statistical center in 2016 [1]

The research that has been conducted by [2] aims to assist village and community units to know the ranking of the head of village candidate from the weighted criteria determined so as to provide additional information as citizens will make their choice. Research conducted by [3] aims to assist and facilitate in assessing the performance of lecturers based on predetermined criteria.

From some studies of previous researchers that have been done above, the use of Simple Additive Weighting method to find weighted sums with the criterion of assessment is more in terms of physical and academic for lecturers and prospective village head. While in this study to measure the index heads of village from several villages in Pagelaran sub-district assessment criteria are more seen in the aspect of competence and performance.

The effort to improve the quality of the head of village is to apply some predetermined criteria of assessment and apply the Simple Additive Weighting method to find the weighted sum of the performance rating by performing an index measurement to determine the maximum or absence head of village performance in each village Pagelaran sub-district.

Given the measurement of village head indexes, the heads of village may trigger village heads to improve their performance in building their villages to become more advanced by using predetermined criteria and applying the Simple Additive Weighting method to simplify the assessment or measure the best index on the performance heads of village Pagelaran sub-district. 


\section{THEORETICAL REVIEW}

\section{A. Decision Support System}

Decision Support System (DSS) is a system to support decision makers to solve and solve semi-structured problems. DSS aims as a tool for decision-makers to expand their abilities, but not to replace their judgments[4]. Man and Watson propose Decision Support System is an interactive system that helps decision makers through the use of semi-structured and unstructured data and decision models [5]. Proposes that the types of decisions are grouped into two kinds, one of which is the first programmed decision, this decision is related to a known issue, and the decision making is routine and scheduled. The second the decision is not programmed, this decision is new because it deals with new problems and can be said with a fairly complicated problem [6][7].

There are three components of decision support system that is the first is data management serves as a provider of data required by the system. The second management model through the base management model does a good interaction with the user interface to get commands from the data management to get the data to be processed. The third user interface is the most important component in the decision support system because it works to interact between users with the system, either to enter information to the system and display information to the user[8].

\section{B. Fuzzy Multiple Attribute Decision Making}

Fuzzy Multiple Attribute Decision Making (FMADM) is a method to determine the weight value in each attribute, and then proceed into the ranking process that will select the alternatives already given[9][10]. Basically, there are three kinds of approaches for finding attribute weights; they are subjective approach, objective approach and integration approach. Between subjective and objective, each has its own way of determining the weight value of each alternative. In a subjective approach, the weighted value is determined by the subjectivity of the decision-makers, so that several factors in the alternative ranking process can be freely determined. As for the objective approach, the weighted value is mathematically calculated so that it ignores the subjectivity of the decision maker. There are several methods that can be used for FMADM completion, among others [11][12]:

a. Simple Additive Weighting (SAW)

b. Weighted Product (WP)

c. ELECTRE

d. Technique for Order Preference by Similarity to Ideal Solution (TOPSIS)

e. Analytic Hierarchy Process (AHP)

\section{Head of Village}

The head of village is the leader of the village level government and as the leader of the village administration. The head of village is the person responsible for his village to bring his village towards a more advanced; teaching his community to become an active person, hence the performance assessment of village heads is conducted. The village head who has established criteria of gender, has been held for a long time as a head of village, judged by the existing facilities and infrastructure of each village, the achievement of the program from the national family planning program and its target and realization of the UN, in terms of community welfare [13].

\section{RESEARCH METHODS}

\section{A. Simple Additive Weighting Method}

Simple Additive Weighting is a weighted sum method with the basic concept of seeking the weighted sum of performance ratings on each alternative on each attribute[14][15][16]. Simple Additive Weighting completion step:

a. Determining the criteria used as a reference in decision making, namely $\mathrm{Ci}$.

b. Specify an alternative loyal match rating on each criterion.

c. Create a matrix.

$\mathrm{d}$. The final result is obtained from ranking results.

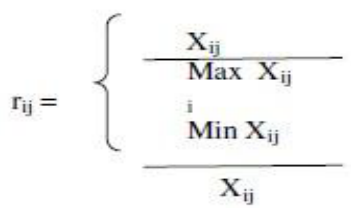

Information :

Rij : normalized performance rating value

$\mathrm{Xij} \quad$ : row and column matrix

Max Xij : the largest value of each criterion

Min Xij : the smallest value of faithful criteria[17]

\section{B. Weight Criteria}

In this study there are weights and criteria needed to determine the village heads who carry out their obligations in earnest [18-20]. The criteria are:

C1: Gender

C2 : How Long Served

C3 : Facilities and Infrastructure

C4 : Program Achievement

C5 : Community Welfare

\section{RESULTS AND DISCUSSION}

\section{A. Calculation of Criteria Weights}

The method of calculation of simple additive weighting method is the result of the process of inputting the data of village head that has been changed based on the weight of the criteria that have been determined through the calculation process.

Tabel 2 Gender Criteria

\begin{tabular}{|l|c|}
\hline \multicolumn{1}{|c|}{ Gender } & Value \\
\hline Woman & 0,4 \\
\hline Man & 0,8 \\
\hline
\end{tabular}

Tabel 3. Criteria How Long Have Been officiate 


\begin{tabular}{|l|c|}
\hline \multicolumn{1}{|c|}{ Long } & Value \\
\hline 1-2 Year & 0,2 \\
\hline 2-3 Year & 0,4 \\
\hline 3-4 Year & 0,6 \\
\hline 4-5 Year & 0,8 \\
\hline 5-6 Year & 1 \\
\hline
\end{tabular}

Table 4. Criteria for Facilities and Infrastructure

\begin{tabular}{|l|c|}
\hline \multicolumn{1}{|c|}{ Facilities and Infrastructure } & Value \\
\hline Not good & 0,2 \\
\hline Good enough & 0,6 \\
\hline Good & 0,8 \\
\hline Very good & 1 \\
\hline
\end{tabular}

Table 5. Program Achievement Criteria

\begin{tabular}{|l|l|}
\hline \multicolumn{1}{|c|}{ Program Achievement } & \multicolumn{1}{c|}{ Value } \\
\hline Less Match & 0,2 \\
\hline Simply Match & 0,6 \\
\hline Corresponding & 0,8 \\
\hline Very Match & 1 \\
\hline
\end{tabular}

Table 6. Criteria for Community Welfare

\begin{tabular}{|l|l|}
\hline Community Welfare & Value \\
\hline Very low & 0,2 \\
\hline Low & 0,4 \\
\hline Enough & 0,6 \\
\hline High & 0,8 \\
\hline Very high & 1 \\
\hline
\end{tabular}

Table 7. Weight Each Criterion

\begin{tabular}{|l|l|}
\hline Criteria & Value \\
\hline C1 & 0,10 \\
\hline C2 & 0,20 \\
\hline C3 & 0,25 \\
\hline C4 & 0,20 \\
\hline C5 & 0,25 \\
\hline
\end{tabular}

From the existing criteria and then weighted then made variables that will be converted into fuzzy numbers that weight the value as follows:

1. Very low $(\mathrm{SR}) \quad=0$

2. $\operatorname{Low}(\mathrm{R})=0.2$

3. $\operatorname{Medium}(\mathrm{S})=0.4$

4. Middle $(\mathrm{T} 1)=0.6$

5. Height $(\mathrm{T} 2)=0.8$

6. Very high $(\mathrm{ST})=1$

To get the variable is made a graph in figure 1 :

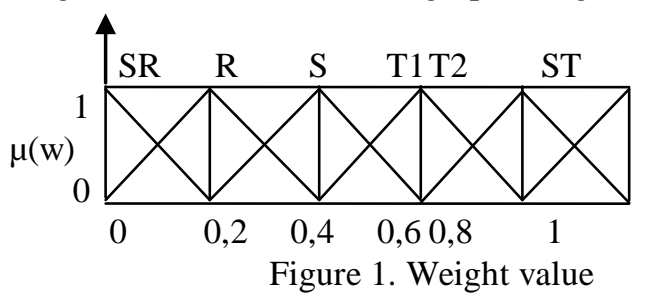

Alternative names of village heads:

A1 = Sudiyono (Patoman)
A2 = Hariyono (Panutan)
A3 = Mahrom (Pagelaran)
A4 = Maniso (Gemaripah)
A5 = Surono (Gumukmas)
A6 = Wagiman (Gumukrejo)
A7 = Ismali (Bumiratu)
A8 = Burhanudin, ST (Sukawangi)
A9 = Darman (Ganjaran)
A10 $=$ Supriyono (Karangsari)

Table 8. Weighting each Alternative Criteria

\begin{tabular}{|c|c|c|c|c|c|}
\hline $\begin{array}{l}\text { Alternativ } \\
\text { e }\end{array}$ & C1 & C2 & C3 & C4 & C5 \\
\hline A1 & 0,8 & 0,8 & 0,8 & 0,6 & 0,8 \\
\hline A2 & 0,8 & 0,8 & 0,8 & 0,6 & 0,6 \\
\hline A3 & 0,8 & 0,8 & 1 & 0,8 & 0,8 \\
\hline A4 & 0,8 & 0,8 & 0,2 & 0,2 & 0,6 \\
\hline A5 & 0,8 & 0,8 & 0,6 & 0,6 & 0,8 \\
\hline A6 & 0,8 & 0,6 & 0,6 & 0,8 & 0,6 \\
\hline A7 & 0,8 & 0,2 & 0,8 & 0,6 & 0,6 \\
\hline A8 & 0,8 & 0,2 & 0,2 & 0,2 & 0,2 \\
\hline A9 & 0,8 & 0,6 & 0,6 & 0,2 & 0,2 \\
\hline A10 & 0,8 & 0,8 & 0,6 & 0,8 & 0,6 \\
\hline
\end{tabular}

\section{B. Calculation}

\section{Normalization for Each Matrix}

Kriteria Benefit $(\mathrm{C} 1, \mathrm{C} 2, \mathrm{C} 3, \mathrm{C} 4, \mathrm{C} 5)$

$\mathrm{Rii}=(\mathrm{Xij} / \max \{\mathrm{Xij}\}$

From column $\mathrm{C} 1$ the maximum value is 0.8 then each row column $\mathrm{A}$ is divided by the maximum value of column C1.

$\mathrm{R} 1,1=0,8 / 0,8=1$

$\mathrm{R} 2,1=0,8 / 0,8=1$

$\mathrm{R} 3,1=0,8 / 0,8=1$

$\mathrm{R} 4,1=0,8 / 0,8=1$

$\mathrm{R} 5,1=0,8 / 0,8=1$

R6, $1=0,8 / 0,8=1$

$\mathrm{R} 7,1=0,8 / 0,8=1$

$\mathrm{R} 8,1=0,8 / 0,8=1$

R9, $1=0,8 / 0,8=1$

$\mathrm{R} 10,1=0,8 / 0,8=1$

From column $\mathrm{C} 2$ the maximum value is 0.8 then each row of column $\mathrm{A}$ is divided by the maximum value of column $\mathrm{C} 2$.

$\mathrm{R} 1,2=0,8 / 0,8=1$

$\mathrm{R} 2,2=0,8 / 0,8=1$

$\mathrm{R} 3,2=0,8 / 0,8=1$

$\mathrm{R} 4,2=0,8 / 0,8=1$

$\mathrm{R} 5,2=0,8 / 0,8=1$

R6, $2=0,6 / 0,8=0,75$

$\mathrm{R} 7,2=0,2 / 0,8=0,25$

$\mathrm{R} 8,2=0,2 / 0,8=0,25$

$\mathrm{R} 9,2=0,6 / 0,8=0,75$

$\mathrm{R} 10,2=0,8 / 0,8=1$

From column C3 the maximum value is 1 then each row of column $\mathrm{A}$ is divided by 
the maximum value of column $\mathrm{C} 3$.
$\mathrm{R} 1,3=0,8 / 1=0,8$
$\mathrm{R} 2,3=0,8 / 1=0,8$
$\mathrm{R} 3,3=1 / 1=1$
$\mathrm{R} 4,3=0,2 / 1=0,2$
$\mathrm{R} 5,3=0,6 / 1=0,6$
$\mathrm{R} 6,3=0,6 / 1=0,6$
$\mathrm{R} 7,3=0,8 / 1=0,8$
$\mathrm{R} 8,3=0,2 / 1=0,2$
$\mathrm{R} 9,3=0,6 / 1=0,6$
$\mathrm{R} 10,3=0,6 / 1=0,6$

From column $\mathrm{C} 4$ the maximum value is 0.8 then each row of column $\mathrm{A}$ is divided by the maximum value of column C4.

$\mathrm{R} 1,4=0,6 / 0,8=0,75$

$\mathrm{R} 2,4=0,6 / 0,8=0,75$

$\mathrm{R} 3,4=0,8 / 0,8=1$

$\mathrm{R} 4,4=0,2 / 0,8=0,25$

$\mathrm{R} 5,4=0,6 / 0,8=0,75$

R6, $4=0,8 / 0,8=1$

$\mathrm{R} 7,4=0,6 / 0,8=0,75$

$\mathrm{R} 8,4=0,2 / 0,8=0,25$

$\mathrm{R} 9,4=0,2 / 0,8=0,25$

$\mathrm{R} 10,4=0,8 / 0,8=1$

From column C5 the maximum value is 0.8 then each row of column $\mathrm{A}$ is divided by the maximum value of column C5.

$\mathrm{R} 1,5=\mathrm{O}, 8 / 0,8=1$

$\mathrm{R} 2,5=0,6 / 0,8=0,75$

$\mathrm{R} 3,5=0,8 / 0,8=1$

$\mathrm{R} 4,5=0,6 / 0,8=0,75$

$\mathrm{R} 5,5=0,8 / 0,8=1$

R6, $5=0,6 / 0,8=0,75$

R7, $5=0,6 / 0,8=0,75$

$\mathrm{R} 8,5=0,2 / 0,8=0,25$

$\mathrm{R} 9,5=0,2 / 0,8=0,25$

$\mathrm{R} 10,5=0,6 / 0,8=0,75$

Table 9. Normalized Factor Results

\begin{tabular}{|c|c|c|c|c|c|}
\hline $\begin{array}{l}\text { Alternativ } \\
\text { e }\end{array}$ & C1 & C2 & C3 & C4 & C5 \\
\hline A1 & 1 & 1 & 0,8 & 0,75 & 1 \\
\hline A2 & 1 & 1 & 0,8 & 0,75 & 0,75 \\
\hline A3 & 1 & 1 & 1 & 1 & 1 \\
\hline A4 & 1 & 1 & 0,2 & 0,25 & 0,75 \\
\hline A5 & 1 & 1 & 0,6 & 0,75 & 1 \\
\hline A6 & 1 & 0,75 & 0,6 & 1 & 0,75 \\
\hline A7 & 1 & 0,25 & 0,8 & 0,75 & 0,75 \\
\hline A8 & 1 & 0,25 & 0,2 & 0,25 & 0,25 \\
\hline A9 & 1 & 0,75 & 0,6 & 0,25 & 0,25 \\
\hline A10 & 1 & 1 & 0,6 & 1 & 0,75 \\
\hline
\end{tabular}

By multiplying each column of the table by the weight of the declared criteria.

Vector weight:

$\mathrm{C} 1=0,10$

$\mathrm{C} 2=0,20$

$\mathrm{C} 3=0,25$

$\mathrm{C} 4=0,20$
$\mathrm{C} 5=0,25$

With the equation of preference values for each alternative (Vi):

$V_{i}=\sum_{j=1}^{n} w_{j} r_{i j}$

$\mathrm{Vi}$ : preference value

$\mathrm{Wj}$ : rating weight

Rij : normalized performance rating value

$$
\begin{aligned}
& \mathrm{V} 1 \quad \begin{array}{l}
\quad(1 \times 0,10)+(1 \times 0,20)+(0,8 \times 0,25)+(0,75 \times \\
0,20)+(1 \times 0,25)
\end{array} \\
& =0,1+0,2+0,2+0,15+0,25 \\
& =0,9
\end{aligned}
$$

V2 $=(1 \times 0,10)+(1 \times 0,20)+(0,8 \times 0,25)+(0,75 \times$ $0,20)+(0,75 \times 0,25)$

$=0,1+0,2+0,2+0,15+0,18$

$=0,83$

V3

$$
\begin{aligned}
& =(1 \times 0,10)+(1 \times 0,20)+(1 \times 0,25)+ \\
& (1 \times 0,20)+(1 \times 0,25) \\
& =0,1+0,2+0,25+0,20+0,25 \\
& =1
\end{aligned}
$$

$$
\text { V4 } \begin{aligned}
\quad & =(1 \times 0,10)+(1 \times 0,20)+(0,2 \times 0,25)+0,25 \times 0,20) \\
& +(0,75 \times 0,25) \\
= & 0,1+0,2+0,05+0,05+0,18 \\
= & 0,58
\end{aligned}
$$

V5

$$
\begin{aligned}
& =(1 \times 0,10)+(1 \times 0,20)+(0,6 \times 0,25)+(0,75 \times \\
& 0,20)+(1 \times 0,25) \\
& =0,1+0,2+0,15+0,15+0,25 \\
& =0,85
\end{aligned}
$$

V6

$$
\begin{aligned}
& 6 \begin{array}{l}
=(1 \times 0,10)+(0,75 \times 0,20)+(0,6 \times 0,25)+(1 \times \\
0,20)+(0,75 \times 0,25)
\end{array} \\
& =0,1+0,15+0,15+0,20+0,18
\end{aligned}
$$$$
=0,78
$$

$$
\text { V7 } \begin{aligned}
& \quad=(1 \times 0,10)+(0,25 \times 0,20)+(0,8 \times 0,25)+(0,75 \times \\
& 0,20)+(0,75 \times 0,25) \\
& =0,1+0,05+0,2+0,15+0,18 \\
& =0,68
\end{aligned}
$$

$$
\begin{array}{ll}
\text { V8 } & =(1 \times 0,10)+(0,25 \times 0,20)+(0,2 \times 0,25)+(0,25 \times \\
& 0,20)+(0,25 \times 0,25) \\
= & 0,1+0,05+0,05+0,05+0,06 \\
= & 0,31
\end{array}
$$

$$
\text { V9 } \begin{aligned}
& =(1 \times 0,10)+(0,75 \times 0,20)+(0,6 \times 0,25)+(0,25 \times \\
& 0,20)+(0,25 \times 0,25) \\
= & 0,1+0,15+0,15+0,05+0,06 \\
= & 0,51
\end{aligned}
$$

$$
\begin{aligned}
& \mathrm{V} 10 \quad \begin{array}{l}
= \\
\end{array} \\
& \quad+(0,75 \times 0,25) \\
& =0,1+0,2+0,15+0,2+ \\
& 0,18 \\
& =0,83 \\
& \quad \begin{array}{l}
\text { Published By: } \\
\text { Blue Eyes Intelligence Engineering } \\
\text { \& Sciences Publication }
\end{array}
\end{aligned}
$$


Among V1, V2, V3, V4, V5, V6, V7, V8, V9, V10 the largest value is V3 with an alternative Village Pagelaran with a weight of value 1 .

\section{ANALYSIS OF RESULTS}

Based on the results of SAW calculation can be seen in the following table:

Table 10. Final result of SAW

\begin{tabular}{|c|l|c|}
\hline No & \multicolumn{1}{|c|}{ Name } & Final result \\
\hline 1 & Patoman Village & 0,9 \\
\hline 2 & Panutan Village & 0,83 \\
\hline 3 & Pagelaran Village & 1 \\
\hline 4 & Gemaripah Village & 0,58 \\
\hline 5 & Gumukmas Village & 0,85 \\
\hline 6 & Gumukrejo Village & 0,78 \\
\hline 7 & Bumiratu Village & 0,68 \\
\hline 8 & Sukawangi Village & 0,31 \\
\hline 9 & Ganjaran Village & 0,51 \\
\hline 10 & Karangsari Village & 0,83 \\
\hline
\end{tabular}

From the data above table concluded with the following figure 2:

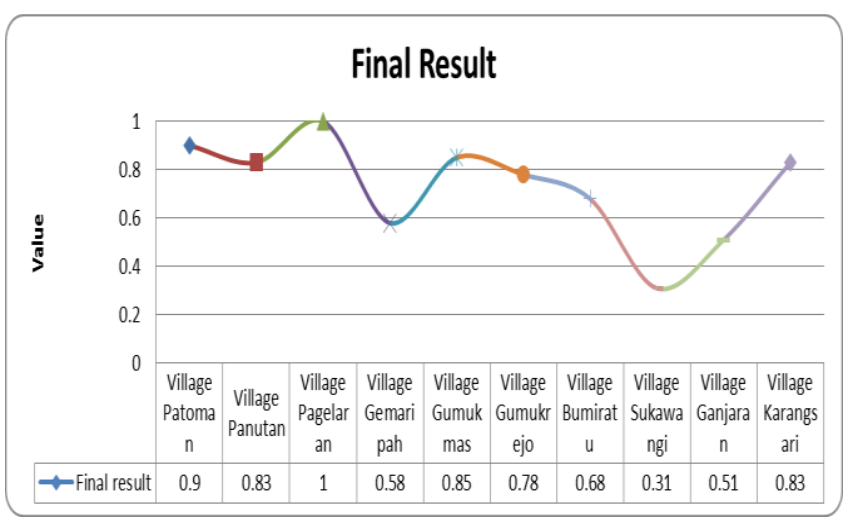

Figure 2. Graph of assessment index of village head of Pagelaran sub-district.

\section{V.CONCLUSION}

Decision support system by using Simple Additive Weighting in measuring village head index in Pagelaran sub-district can trigger in improving performance of village head to build village based on predetermined criteria. Of the ten tested alternatives in highest scores were A3 with an alternative named Mahrom who was the head of Pagelaran village.

\section{REFERENCES}

[1] BPSPringsewu, Kecamatan Pringsewu Dalam Angka 2017. 2017.

[2] A. Romadoni, "Sistem Pendukung Keputusan Seleksi Pemilhan Calon Kepala Desa Berbasis Web," Skripsi UMS, pp. 1-15, 2014.

[3] M. Muslihudin, F. Triananingsih, and L. Anggraei, "Pembuatan Model Penilaian Indeks Kinerja Dosen Menggunakan Metode Fuzzy Simple Additive Weighting," SEMNASTEKNOMEDIA, vol. 5, no. 1, pp. 25-30, 2017.

[4] T. Noviarti, M. Muslihudin, R. Irviani, and A. Maseleno,
"Optimal Dengue Endemic Region Prediction using Fuzzy Simple Additive Weighting based Algorithm," Int. J. Pure Appl. Math., vol. 118, no. 7, pp. 473-478, 2018.

[5] S. Mukodimah, M. Muslihudin, A. Andoyo, S. Hartati, and A. Maseleno, "Fuzzy Simple Additive Weighting and its Application to Toddler Healthy Food," Int. J. Pure Appl. Math., vol. 118, no. 7, pp. 1-7, 2018

[6] E. Turban, R. Sharda, and D. Delen, Decision Support and Business Intelligence Systems. Chapter 6 Artificial Neural Networks for Data Mining, vol. 8th. 2007.

[7] M. AUGIER, "Administrative Behavior: A Study of Decision-Making Processes in Administrative Organizations. By SIMON (HERBERT A.).," Econ. J., vol. 112, no. 480, pp. F386-F388, 2002.

[8] E. Turban, J. E. Aronson, and T.-P. Liang, "Decision Support Systems and Intelligent Systems," Decis. Support Syst. Intell. Syst., vol. 7, p. 867, 2007.

[9] W. Waziana, R. Irviani, I. Oktaviani, F. Satria, D. Kurniawan, and A. Maseleno, "Fuzzy Simple Additive Weighting for Determination of Recipients Breeding Farm Program," vol. 118, no. 7, pp. 93-100, 2018.

[10] R. Irviani, I. Dinulhaq, D. Irawan, R. Renaldo, and A. Maseleno, "Areas Prone of the Bad Nutrition based Multi Attribute Decision Making with Fuzzy Simple Additive Weighting for Optimal Analysis," Int. J. Pure Appl. Math., vol. 118, no. 7, pp. 589-596, 2018.

[11] S. Kusumadewi, S. Hartati, A. Harjoko, and Retanto Wardoyo, Fuzzy Multi-Attribute Decision Making (Fuzzy MADM). Yogyakarta: Graha Ilmu, 2013.

[12] M. Muslihudin, T. S. Susanti, A. Maseleno, and $S$. Pringsewu, "The Priority of Rural Road Development using Fuzzy Logic based Simple Additive Weighting," Int. J. Pure Appl. Math., vol. 118, no. 8, pp. 9-16, 2018.

[13] Z. Siti Muqodimah, Muhamad Muslihudin, Andino Maseleno, "Measuring Index Performance Village Heads On Sub Distric Pringsewu Uses The Method Weighted Product," in ICSTIEM, 2017, p. 6.

[14] A. Hidayat, M. Muslihudin, and I. T. Utami, "Sistem Pendukung Keputusan Menentukan Lokasi Cafe Baru Suncafe Sebagai Destinasi Wisata Kuliner Di Kabupaten Pringsewu Menggunakan Metode Simple Additive Weighting (SAW), " J. TAM ( Technol. Accept. Model ), vol. 6, no. 1, pp. 71-79, 206AD.

[15] M. Muslihudin and M. Gumanti, "A System To Support Decision Makings In Selection Of Aid Receivers For Classroom Rehabilitation For Senior High Schools By Education Office Of Pringsewu District By," IJISCS, vol. 1, no. 2, pp. 1-9, 2017.

[16] M. Muslihudin, D. Kurniawan, and I. Widyaningrum, "Implementasi Model Fuzzy SAW Dalam Penilaian Kinerja Penyuluh Agama,” J. TAM ( Technol. Accept. Model ), vol. 8, no. 1, pp. 39-44, 2017.

[17] A. Andoyo, M. Muslihudin, and N. Y. Sari, "Pembuatan Model Penilaian Indeks Kinerja Dosen Menggunakan Metode Fuzzy Multi Attribute Decision Making ( FMADM ) ( Studi: PTS di Provinsi Lampung )," in Prosiding Seminar Nasional Darmajaya, 2017, pp. 195-205.

[18] Sycheva, I. N., Ovchinnicov, Y. L., Voronkova, O. $\quad$. U., Akhmetshin, E. M., Kolmakov, V. V., \& Vasilieva, A. G. (2018). Economic potential and development prospects of small businesses in rural areas. European Research Studies Journal, 21(4), 292-303.

[19] Ibatova, A. Z. (2018). Implementation of ISO principles in engineers' training. International Journal of Civil Engineering and Technology, 9(3), 515-521.

[20] Voronkova, O. Y., Akhmetshin, E. M., Sycheva, I. N., Shpakova, R. N., Pashkova, E. Y., \& Poltarykhin, A. L. (2018). Economic mechanism of regulating land relations in the agricultural sector of Russia. European Research Studies Journal, 21(4), 280-291. 